\section{Severe Meesmann's epithelial corneal dystrophy phenotype due to a missense mutation in the helix- initiation motif of keratin 12}

H Hassan' ${ }^{1}$ C Thaung², ND Ebenezer², G Larkin², AJ Hardcastle ${ }^{2}$ and SJ Tuft',2

\begin{abstract}
Purpose To describe a severe phenotype of Meesmann's epithelial corneal dystrophy (MECD) and to determine the underlying molecular cause.

Methods We identified a 30-member family affected by MECD and examined 11 of the 14 affected individuals. Excised corneal tissue from one affected individual was examined histologically. We used PCR and direct sequencing to identify mutation of the coding regions of the KRT3 and KRT12 genes.
\end{abstract}

Results Cases had an unusually severe phenotype with large numbers of intraepithelial cysts present from infancy and they developed subepithelial fibrosis in the second to third decade. In some individuals, the cornea became superficially vascularized, a change accompanied by the loss of clinically obvious epithelial cysts. Visual loss from amblyopia or corneal opacity was common and four individuals were visually impaired ( $\leq 6 / 24$ bilaterally) and one was blind ( $<6 / 60$ bilaterally). In all affected family members, there was a heterozygous missense mutation c. 395T $>C$ (p. L132P) in exon 1 of the KRT12 gene, which codes for the helix-initiation motif of the K12 polypeptide. This sequence change was not found in unaffected family members or in 100 unaffected controls.

Conclusions The Leu132Pro missense mutation is within the helix-initiation motif of the keratin and is predicted to result in a significant structural change of the K12 protein. The clinical effects are markedly more severe than the phenotype usually associated with the Arg135Thr mutation within this motif, most frequently seen in European patients with MECD.

Eye (2013) 27, 367-373; doi:10.1038/eye.2012.261; published online 7 December 2012

Keywords: corneal epithelium; Meesmann corneal dystrophy; human KRT12 protein

Introduction

Meesmann's epithelial corneal dystrophy (MECD; OMIM \#122100) is an autosomal dominant inherited change of the corneal epithelium of the eye characterized by the bilaterally symmetric development of numerous intraepithelial cysts. ${ }^{1,2}$ The cysts are best visualized on retroillumination and they are most obvious in the inter-palpebral zone. They are typically $50 \mu \mathrm{m}$ in diameter when measured in vivo using confocal microscopy. Although some cases are mild or almost asymptomatic, it is more usual for there to be photophobia, discomfort, epiphora, and blurred vision. Phenotypic variation within families has been described with differences in the numbers and distribution of the cysts within the corneal epithelium. ${ }^{3}$ The number of cysts tends to increase with age but significant visual loss is unusual. However, painful recurrent corneal epithelial erosion and subepithelial fibrosis, particularly in older individuals, has been described, ${ }^{1-4}$ which may cause visual reduction
${ }^{1}$ Corneal Service, Moorfields Eye Hospital NHS Foundation Trust, London, UK

${ }^{2}$ Department of Ocular Biology and Therapeutics, UCL Institute of Ophthalmology, London, UK

Correspondence: SJ Tuft, Clinical Ophthalmology, Moorfields Eye Hospital, 162 City Road, London EC1V 2PD, UK.

Tel: + $44(0) 207566$ 2045;

Fax: + 44 (0)207 5662019 .

E-mail: s.tuft@ucl.ac.uk

Received: 22 June 2012 Accepted in revised form: 31 October 2012 Published online: 7 December 2012 


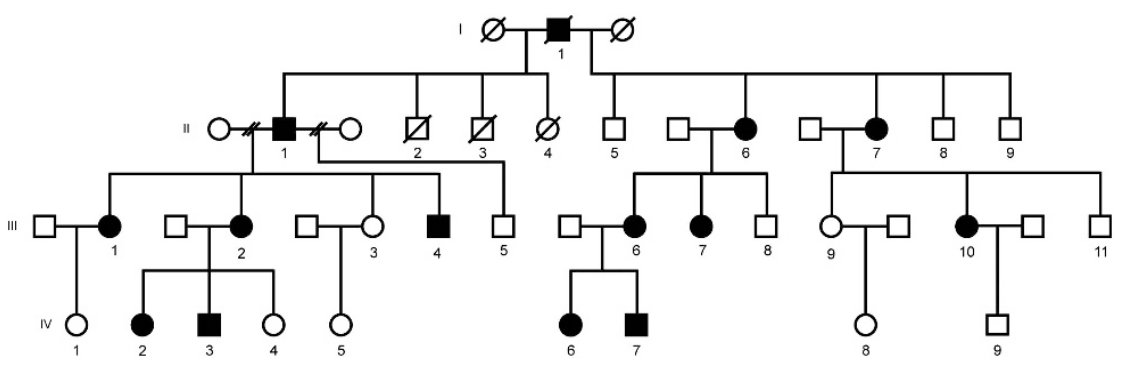

Figure 1 Pedigree of the MECD study family showing autosomal dominant inheritance. Filled circles (female) and squares (male) indicate affected status. Unfilled symbols are unaffected individuals. Strike through indicates deceased.

from irregular corneal astigmatism and opacity. ${ }^{4}$ Light microscopy of excised corneal tissue from cases of MECD demonstrates a thickened basement membrane with periodic acid Schiff (PAS)-positive material deposited on the epithelial basement membrane and within the epithelial cells. Electron microscopy shows intracytoplasmic cysts filled with electron dense material. 5,6

The molecular basis for MECD is a mutation of either the KRT3 or KRT12 genes encoding keratins K3 (type II) or K12 (type I). ${ }^{7}$ Keratins are proteins that are a component of intermediate filaments that, with microfilaments and microtubules, form the flexible cytoskeleton scaffold found in the cytoplasm of epithelial cells. ${ }^{8}$ The genes encoding human keratins are located in two compact, gene-dense clusters on chromosomes 17q12-q21 (type I keratins) and 12q11-q13 (type II keratins). ${ }^{9}$ Functionally, it is usual for a type I (acidic) keratin to bind with a specific type II (basic or neutral) keratin to form an obligate heterodimer. ${ }^{10}$ At the $\mathrm{N}$ - and C-termini, flanking the central rod domain of the keratin proteins, are highly conserved helix-initiation and helix-termination motifs. ${ }^{8}$ These motifs are crucial for hetrodimerization, protein coiling, and keratin fiber assembly, and are known to be mutation hot spots. Disruption of either of the constituent keratins in the heterodimer pair results in cell fragility and disruption. ${ }^{11}$ To date, mutations in over 54 different keratin genes have been shown to cause over 90 different clinical disorders of human epidermal and epithelial structure. ${ }^{9,12}$ These act as dominant negative (antimorphic) mutations in which the defective gene product acts antagonistically to the product of the wild-type allele.

Numerous disease causing mutations within the coding region of either the KRT12 gene (21 mutations) or the KRT3 gene (three mutations) have been described for MECD. All mutations reported to date are missense point mutations, with the exception of one frameshift mutation in exon 6 of the KRT12 gene. ${ }^{4,9,13}$ KRT12 (exons 1 or 6 ) and KRT3 (exon 7) mutations are confined to those regions encoding the helix-initiation or helix-termination motifs and they are highly detrimental to intermediate filament structure. ${ }^{8}$ Here, we report a large family with a missense mutation c. 395T > C (p. L132P) within exon 1 of the KRT12 gene in the helix-initiation motif of the K12 protein that is associated with a very severe phenotype characterized by corneal scarring, neovascularization, and marked visual loss and amblyopia in some individuals.

\section{Patients and methods}

The local ethics review board approved this study and we adhered to the guidelines of the Declaration of Helsinki. Following informed consent, two observers (GL and ST) examined all available members of a large white UK family with MECD that exhibited autosomal dominant inheritance (Figure 1). The phenotype was confirmed at slit lamp biomicroscopy and photographs taken. Vision was measured as Snellen acuity with best available visual correction and pinhole viewing.

\section{Histological examination}

The full thickness cornea from individual 2:1 (age 78 years) was fixed in $10 \%$ neutral-buffered formalin. It was then processed into paraffin wax. We cut $4 \mu \mathrm{m}$ sections that were then stained with hematoxylin and eosin and PAS stains by conventional methods. Subsequently, part of the cornea specimen was dewaxed and reprocessed into resin for electron microscopy. Semi-thin $(750 \mathrm{~nm})$ resin sections were stained with Toluidine blue for light microscopy, and then ultrathin $(80 \mathrm{~nm})$ sections cut and stained with uranyl acetate. These were examined on a JEOL 1010, transmission electron microscope (Welwyn Garden City, UK).

\section{Molecular genetics}

Genomic DNA was extracted from peripheral blood samples from all participating family members using standard methods. Exon 7 of the KRT3 gene encoding K3 and exons 1 and 6 of the KRT12 gene encoding K12 were 
selected for initial sequence analysis. The primers used for amplification are available on request.

Exons were amplified in a PCR reaction of $25 \mu \mathrm{l}$ composed of $150 \mathrm{ng}$ DNA $(3 \mu \mathrm{l}), 12.5 \mu \mathrm{l} 2 \times$ Mastermix (AB-0575, Abgene, Thermo Fisher Scientific, Waltham, MA, USA), $3 \mu \mathrm{l}$ of $2 \mathrm{mM}$ forward primer, $3 \mu \mathrm{l}$ of $2 \mathrm{mM}$

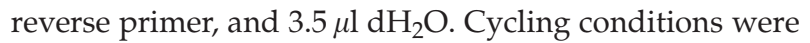
$94^{\circ} \mathrm{C}$ for $5 \mathrm{~min}$ followed by 34 cycles of $94^{\circ} \mathrm{C}$ for $30 \mathrm{~s}$, annealing temperature (Ta) ${ }^{\circ} \mathrm{C}$ for $30 \mathrm{~s}, 72{ }^{\circ} \mathrm{C}$ for $45 \mathrm{~s}$, followed by 1 cycle of $72{ }^{\circ} \mathrm{C}$ for $5 \mathrm{~min}$. PCR products were analyzed by agarose gel electrophoresis. All amplified products were then enzymatically purified.

A $2-\mu \mathrm{l}$ volume of PCR product was added to $1 \mu \mathrm{l}$ ExoSAP-IT (GE Healthcare Ltd, Little Chalfont, UK) to a final volume of $26 \mu \mathrm{l}$. The samples were incubated at $37^{\circ} \mathrm{C}$ for $15 \mathrm{~min}$ and heat inactivated at $80^{\circ} \mathrm{C}$ for $15 \mathrm{~min}$. An aliquot $(13 \mu \mathrm{l})$ of purified PCR product was then bidirectionally sequenced with $1 \mu \mathrm{l}$ of $2 \mu \mathrm{M}$ forward or reverse primer, $1 \mu \mathrm{l}$ BigDye (version 3.1, Applied Biosystems, Paisley, UK) and $5 \mu \mathrm{l}$ sequencing buffer (Applied Biosystems) following the manufacturer protocols. DNA was then precipitated by addition of $26 \mu \mathrm{l}$ precipitation solution $(50 \mathrm{ml} 95 \%$ Ethanol, $2 \mathrm{ml} 3 \mathrm{M}$ $\mathrm{NaOAc} \mathrm{pH}$ 5.2) on ice for $10 \mathrm{~min}$ before centrifugation at 13000 r.p.m. for $30 \mathrm{~min}$. The supernatant was then aspirated, $200 \mu \mathrm{l}$ of $70 \%$ ethanol added to the DNA pellet and the sample was centrifuged at 13000 r.p.m. for $10 \mathrm{~min}$. The DNA pellet was then re-suspended in $11 \mu \mathrm{l}$ formamide and denatured at $95^{\circ} \mathrm{C}$ for $5 \mathrm{~min}$. The samples were analyzed on an ABI 3730 (Applied Biosystems). The sequences generated from affected and unaffected patients were compared with the reference sequence (obtained from UCSC hg19 build) using Lasergene DNA Star software (DNA Star Inc, Madison, WI, USA).

To test for segregation of the mutation in the extended family, exon 1 of the KRT12 gene was amplified and bidirectionally sequenced in all affected and unaffected individuals. A control DNA panel (100 samples, 200 chromosomes) of white UK donors with no known ophthalmic condition (ECACC, Health Protection Agency Culture Collections) was screened to test if the sequence variant was a rare polymorphism. A fragment of exon 1 encompassing the mutation was amplified using F;GAAGTTCCATGGCAGGAGGAC and R;TTGGAAAATATCAAAGTTGTAGGTG as described above. The PCR product was subsequently digested with MseI (New England Biolabs, Hitchin, UK) because the mutation abolished an $\mathrm{Mse}$ I restriction site. A $10-\mu \mathrm{l}$ aliquot of the PCR product was mixed with $5 \mathrm{U}(0.5 \mu \mathrm{l})$
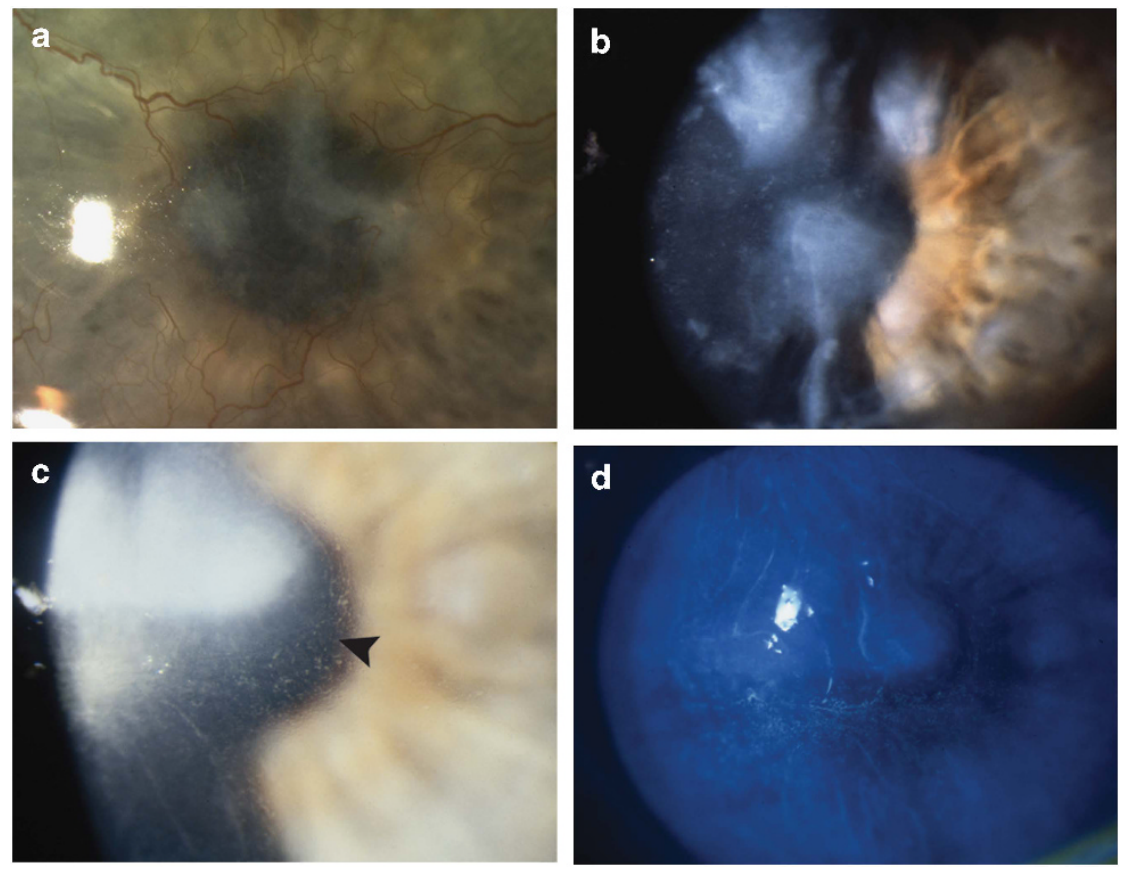

Figure 2 Clinical images of affected patients with severe phenotype of MECD. (a) Left cornea of patient (III: 2). There had been no prior surgery. There is superficial vascularization and areas of subepithelial scar over the pupil. There were only small numbers of microcysts in the epithelial layer. (b) Left cornea of patient (III : 6). There is recurrence of subepithelial nodular degeneration despite two keratoplasty procedures. The abnormal epithelial layer contains numerous microcysts. (c) Right cornea of patient III : 7 who had no prior corneal surgery. There is dense subepithelial fibrosis over the pupil. The epithelial layer contains numerous microcysts (arrowhead). (d) Right cornea of patient III:7. Linear irregularities in the corneal epithelial layer are demonstrated with fluorescein. 
MseI, $2 \mu$ l Buffer 4 (New England Biolabs), $2 \mu$ l of 10XBSA

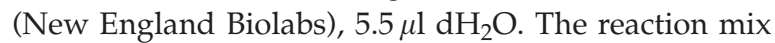
was incubated at $37^{\circ} \mathrm{C}$ for $2 \mathrm{~h}$. The digest was subsequently analyzed on a $2 \%$ agarose gel.

\section{Results}

\section{Clinical features}

The family showed a typical autosomal dominant inheritance pattern (Figure 1). There was considerable variation in the severity of disease but most affected individuals demonstrated a phenotype that was markedly more severe than is usual for MECD (Figure 2). In all individuals, the diagnosis of MECD was confirmed before the age of 6 years, and in two patients the diagnosis was confirmed at 6 weeks of age, although one of these patients (IV:6) maintained good vision (VA $\geq 6$ / 12 ) into her 30s. In young patients, the cysts were almost confluent and with time this was accompanied by the development of a subepithelial fibrosis characteristic of Salzmann nodular degeneration (Figures $2 \mathrm{~b}$ and c). In 5 of the 11 affected individuals examined, there was subepithelial corneal vascularization that developed segmentally and could involve the entire corneal surface (Figure 2a). In areas that had vascularized, there was a marked reduction in the numbers of epithelial cysts in the overlying epithelium. Five of the 11 individuals were managed by keratoplasty, although there was recurrence of disease in all cases. In individual III : 6 recurrent disease after lamellar keratoplasty was treated with phototherapeutic keratectomy, but with further recurrence. The early onset of corneal opacity was associated with presumed amblyopia, and four patients were visually impaired (best corrected acuity $\leq 6 / 24$ bilaterally) and one patient was blind $(<6 / 60$ bilaterally). No other cause for their visual loss (eg, cataract, glaucoma) was identified. Three individuals had eczema and two had asthma, but none had chronic allergic eye disease. The three unaffected family members examined (III:3, III : 8, III :9) had a corrected visual acuity of $\geq 6 / 6$ without ocular abnormalities. The clinical characteristics and associated interventions are summarized in Table 1.

\section{Histological examination}

Light microscopy revealed thinned epithelium with rare microcysts. There was subepithelial deposition of a thick band of PAS-positive material with preservation of the underlying Bowman's layer. The posterior corneal tissue was normal. This subepithelial material was also highlighted on Toluidine blue staining, and on transmission electron microscopy it had an appearance

Table 1 Clinical description of affected family members

\begin{tabular}{|c|c|c|c|c|c|c|c|}
\hline \multirow[t]{2}{*}{ Pedigree number } & \multirow[t]{2}{*}{ Gender } & \multirow[t]{2}{*}{ Age at diagnosis } & \multirow[t]{2}{*}{ Associated disease } & \multicolumn{2}{|c|}{ Secondary pathology and corneal procedures } & \multicolumn{2}{|c|}{ Potential acuity ${ }^{\mathrm{a}}$} \\
\hline & & & & Right eye & Left eye & $R V A$ & LVA \\
\hline I:1 & M & NA & NA & LK & LK & NA & NA \\
\hline II:1 & M & 5 years & Nil & $\begin{array}{l}\text { PK } \\
\text { Scar }\end{array}$ & $\begin{array}{l}\text { PK } \\
\text { Scar }\end{array}$ & $6 / 24$ & $6 / 24$ \\
\hline II:6 & $\mathrm{F}$ & NA & & $\begin{array}{c}\text { LK } \\
\text { Scar } \\
\text { Vascularized } \\
\text { Tarsorrhaphy }\end{array}$ & $\begin{array}{c}\text { Scar } \\
\text { Vascularized } \\
\text { Tarsorrhaphy }\end{array}$ & PL & $1 / 60$ \\
\hline II:7 & $\mathrm{F}$ & 3 years & Asthma & $\begin{array}{c}\text { Scar } \\
\text { Vascularized }\end{array}$ & $\begin{array}{c}\text { Scar } \\
\text { Vascularized }\end{array}$ & $6 / 24$ & $6 / 12$ \\
\hline III:2 & $\mathrm{F}$ & NA & Nil & $\begin{array}{c}\text { PK } \\
\text { Vascularized }\end{array}$ & Vascularized & $6 / 48$ & $4 / 60$ \\
\hline III:6 & $\mathrm{F}$ & 6 weeks & Eczema & $\begin{array}{l}\text { PTK } \\
\text { Scar }\end{array}$ & $\begin{array}{c}\text { LK } \\
\text { PTK } \\
\text { PK }\end{array}$ & $6 / 36$ & $1 / 60$ \\
\hline III:7 & $\mathrm{F}$ & NA & Nil & Scar & Scar & $2 / 60$ & $6 / 18$ \\
\hline III:10 & $\mathrm{F}$ & 3 years & Asthma & Nil & Nil & $6 / 12$ & $6 / 12$ \\
\hline IV:2 & $\mathrm{F}$ & 6 years & Nil & $\begin{array}{c}\text { Vascularized } \\
\text { Scar }\end{array}$ & $\begin{array}{c}\text { Vascularized } \\
\text { Scar }\end{array}$ & $6 / 12$ & $6 / 12$ \\
\hline IV:6 & $\mathrm{F}$ & 6 weeks & Eczema & Nil & Nil & $6 / 12$ & $6 / 9$ \\
\hline IV:7 & M & 1 year & Eczema & $\begin{array}{c}\text { Vascularized } \\
\text { Scar }\end{array}$ & Nil & $6 / 24$ & $6 / 24$ \\
\hline
\end{tabular}

Abbreviations: LE, left eye; LK, lamellar keratoplasty; LVA, left visual acuity; NA, not available; PK, penetrating keratoplasty; PL, perception of light; PTK, phototherapeutic keratectomy; RE, right eye; RVA, right visual acuity; Scar, subepithelial fibrosis..

${ }^{a}$ Best corrected acuity including the use of a rigid contact lens and pinhole viewing. 

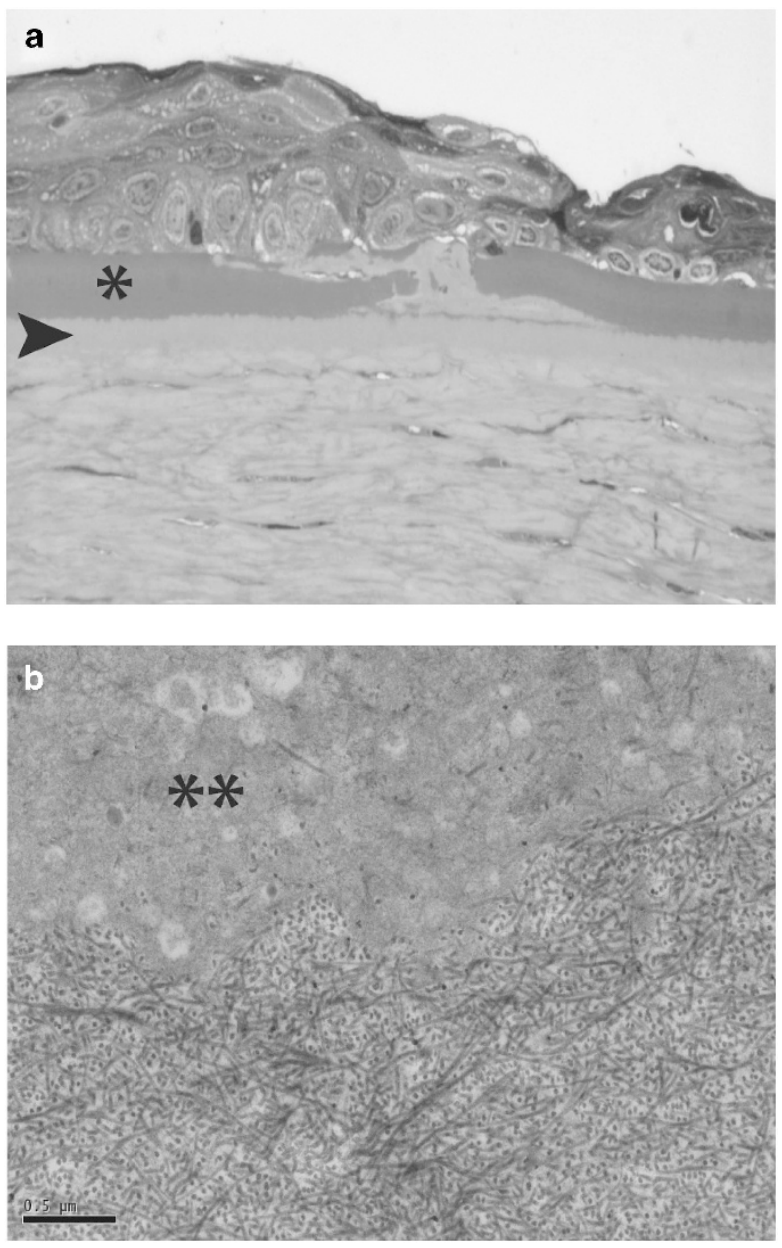

Figure 3 Histological analysis of patient cornea. (a) Right cornea of patient II: 1 at age 78. There is an irregular epithelium with thick discontinuous subepithelial deposit (asterisk). Underlying Bowman's layer (arrowhead) appears unaffected at the level of light microscopy (Toluidine blue, $40 \times$ objective). (b) Transmission electron microscopy of the interface between amorphous subepithelial deposit (double asterisk) and Bowman's layer. Shortened collagen fibrils are evident in Bowman's layer compared with the underlying stroma (not pictured). Scale bar $=0.5 \mu \mathrm{m}$.

suggestive of disorganized basement membrane (Figure 3). The collagen fibrils were shortened compared with the underlying stroma.

\section{Molecular genetics}

PCR amplification and direct sequencing identified a heterozygous sequence change in patient DNA (IV:6), c. 395T >C in exon 1 of KRT12 gene (Figure 4). This sequence change causes a Leucine to Proline missense mutation at amino-acid position 132 (p. L132P). All affected individuals were directly sequenced and found to harbor the c. $395 \mathrm{~T}>\mathrm{C}$ heterozygous mutation. Direct a
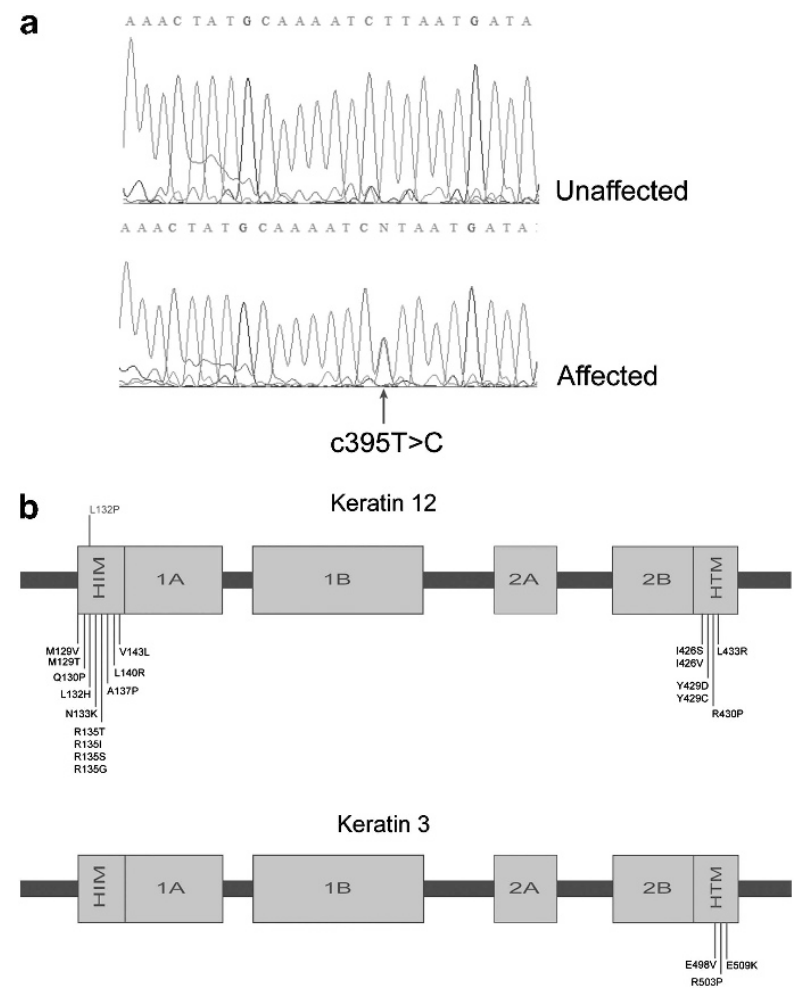

Figure 4 Missense mutation identified in exon 1 of the KRT12 gene encoding the helix-initiation motif. (a) Representative electropherograms of affected and unaffected individuals from the study family showing a c. 395T $>$ C heterozygous missense mutation. (b) Schematic of K3 and K12 showing position of mutations identified causing MECD. HIM, helix-initiation motif; HTM, helix-termination motif. 1A, 1B, 2A, and 2B are subdomains of the central a-helical rod domain. Position of L132P mutation described here is shown above the KRT12 schematic.

sequencing confirmed the absence of the mutation in unaffected family members.

\section{Discussion}

MECD is a bilaterally symmetric autosomal dominant disorder of the corneal epithelium. The condition usually appears with the first years of life but vision is rarely severely affected. Some patients are asymptomatic and the majority of patients require no treatment apart from topical lubricants for mild discomfort. However, even the earliest descriptions of MECD refer to severe cases with opacity of the stroma and destruction of Bowman's layer, but without reference to corneal vascularization. ${ }^{1}$

Superficial keratectomy and lamellar corneal grafting are rarely required but they are established treatments for older patients who have developed corneal opacity, ${ }^{14}$ although the disease can recur after keratoplasty. ${ }^{15}$ We report a family with a severe phenotype of MECD, often associated with permanent visual loss, due to a 
heterozygous missense mutation Leu132Pro in the helixinitiation motif of the K12 polypeptide. ${ }^{16}$ A different missense mutation at this amino-acid site (Leu132His) has previously been reported as a cause of MECD although the authors did not comment on the severity of the phenotype. ${ }^{17}$

Keratins are an essential component of the epithelial cytoskeleton. They have been classified as either type I (acidic keratins; K9-K21) or type II (neutral or basic keratins; K1-K8), and together a pair of keratins from each group will form a heterodimer that is tissue specific and dependent on the stage of cell differentiation. ${ }^{18-20}$ Disruption of the function of either keratin in a heterodimer affects cell structure and the function of the epithelial cell layer. ${ }^{11,21,22}$ Mutation hot spots in the keratin genes are found within the highly conserved helix-initiation and helix-termination motifs. ${ }^{18,23}$ These mutations result in defects of intermediate filament assembly and cell fragility, and at histology intracytoplasmic vacuoles with tonofilament clumping are characteristic. 8,24 The most severe phenotypes of epidermolysis bullosa are associated with mutations in the helix-initiation or helix-termination motifs. ${ }^{16,25}$

K3 and K12 are important components of the intermediate filament cytoskeleton of the corneal epithelium, ${ }^{21,22,26}$ and mutations within either the KRT12 or KRT3 genes cause MECD.7,27 The KRT12 mutations that cause MECD are found in both the helix-initiation and helix-termination motif, while mutations of KRT3 are currently only described in the helix-termination motif (Figure 4). The most common mutation associated with MECD in the European population is a founder effect change in K12, Arg135Thr, that results in relatively mild disease, ${ }^{28}$ but a more severe phenotype has been associated with mutations within both the helixinitiation $^{16,28,29}$ and helix-termination motif. ${ }^{4}$

The present study expands the phenotypic description of MECD and confirms that a mutation in the KRT12 helix-initiation motif can be associated with particularly severe disease, presumably as a result of recurrent epithelial breakdown from epithelial instability. The disease in patients with this mutation can have an early onset that can result in visual deprivation amblyopia. Secondary corneal scarring and vascularization may further reduce vision. Corneal vascularization has not previously been described as a feature of MECD. We could not confirm whether the corneal vascularization was due to recurrent inflammation or overgrowth of the cornea by a conjunctival phenotype following corneal epithelial stem cell failure. Although 5 of the 11 affected members examined had asthma or eczema, none had allergic conjunctivitis and there was no obvious link between the presence of atopy and the presence of severe corneal disease in this family. Histology demonstrated gross subepithelial deposition of PAS-positive material that may have exacerbated the epithelial instability.

Treatment of the severe discomfort, photophobia, or visual loss of MECD remains unsatisfactory.

Symptomatic treatment with topical lubricants or a therapeutic contact lens may be helpful in mild cases. The abnormal epithelium and subepithelial deposits can be removed by debridement or laser superficial keratectomy, but there is usually only temporary relief before epithelial microcysts reappear. Subepithelial fibrosis can be peeled from the underlying Bowman's layer or removed by superficial keratectomy. A lamellar keratoplasty may be required if there is scarring or irregular astigmatism, but we no longer believe that penetrating keratoplasty is justified for this superficial corneal disease. However, although keratoplasty may be temporarily effective it does not address the basic cause for the condition, which is an abnormal epithelium arising from the limbus, and recurrence of the epithelial disease occurs. ${ }^{15}$ Limbal stem cell allo-transplantation may be an alternative to replace the affected epithelial stem cells, while inhibition of the abnormal gene using specific siRNA's to inactivate the mutant allele has been evaluated in vitro and is a promising potential treatment strategy. ${ }^{16}$

\section{Summary}

What was known before

- Meesmann's epithelial corneal dystrophy is caused by mutations of the genes encoding keratin $\mathrm{K} 3$ or K12 The typical clinical picture is of corneal epithelial micro cysts. There is usually photophobia and discomfort but visual loss is unusual.

What this study adds

- The Leu132Pro mutation is associated with a particularly severe phenotype of the disease Corneal scarring, vascularization and amblyopia may result in permanent visual loss.

\section{Conflict of interest}

The authors declare no conflict of interest.

\section{Acknowledgements}

This research was funded by the Department of Health through the award made by the National Institute for Health Research to Moorfields Eye Hospital NHS Foundation Trust and UCL Institute of Ophthalmology for a Specialist Biomedical Research Centre for Ophthalmology (BMRC 089) and by Moorfields Eye Hospital Special Trustees. 


\section{References}

1 Meesmann A. über eine bisher nicht beschriebene, dominant vererbte Dystrophia epithelialis corneae. Ber Zusammenkunft Dtsch Ophthalmol Ges 1938; 52: 154-158.

2 Meesmann A, Wilke F. Klinsche und anatomische Untersuchungen uber eine bisher unbekannte, dominant verebre Epitjeldystrophie der Hornhaut. Klin Monbl Augenheilkd 1939; 103: 361-391.

3 Ehlers N, Hjortdal J, Nielsen K, Thiel HJ, Orntoft T. Phenotypic variability in Meesmann's dystrophy: clinical review of the literature and presentation of a family genetically identical to the original family. Acta Ophthalmol 2008; 86(1): 40-44.

4 Sullivan LS, Baylin EB, Font R, Daiger SP, Pepose JS, Clinch $\mathrm{TE}$ et al. A novel mutation of the Keratin 12 gene responsible for a severe phenotype of Meesmann's corneal dystrophy. Mol Vis 2007; 13: 975-980.

5 Fine BS, Yanoff M, Pitts E, Slaughter FD. Meesmann's epithelial dystrophy of the cornea. Am J Ophthalmol 1977; 83(5): 633-642.

6 Tremblay M, Dube I. Meesmann's corneal dystrophy: ultrastructural features. Can J Ophthalmol 1982; 17(1): 24-28.

7 Irvine AD, Corden LD, Swensson O, Swensson B, Moore JE, Frazer DG et al. Mutations in cornea-specific keratin $\mathrm{K} 3$ or K12 genes cause Meesmann's corneal dystrophy. Nat Genet 1997; 16(2): 184-187.

8 Omary MB, Coulombe PA, McLean WH. Intermediate filament proteins and their associated diseases. $N$ Engl J Med 2004; 351(20): 2087-2100.

9 http://www.interfil.org/index.php. The Human Intermediate Filament Database http://www.interfil.org/ index.php. Updated 6 June 2011. Accessed 11 June 2011. D [H]. G. Accessed 10 June 2011.

10 Chamcheu JC, Siddiqui IA, Syed DN, Adhami VM, Liovic M, Mukhtar H. Keratin gene mutations in disorders of human skin and its appendages. Arch Biochem Biophys 2011; 508(2): 123-137.

11 Kao WW, Liu CY, Converse RL, Shiraishi A, Kao CW, Ishizaki $\mathrm{M}$ et al. Keratin 12-deficient mice have fragile corneal epithelia. Invest Ophthalmol Vis Sci 1996; 37(13): 2572-2584.

12 Szeverenyi I, Cassidy AJ, Chung CW, Lee BT, Common JE, Ogg SC et al. The Human Intermediate Filament Database: comprehensive information on a gene family involved in many human diseases. Hum Mutat 2008; 29(3): 351-360.

13 Howell MD, Kim BE, Gao P, Grant AV, Boguniewicz M, DeBenedetto A et al. Cytokine modulation of atopic dermatitis filaggrin skin expression. J Allergy Clin Immunol 2009; 124(3 Suppl 2): R7-R12.

14 Stocker FW, Holt LB. A rare form of hereditary epithelial dystrophy of the cornea: a genetic, clinical, and pathologic study. Trans Am Ophthalmol Soc 1954; 52: 133-144.

15 Chiou AG, Florakis GJ, Copeland RL, Williams VA, McCormick SA, Chiesa R. Recurrent Meesmann's corneal epithelial dystrophy after penetrating keratoplasty. Cornea 1998; 17(5): 566-570.
16 Liao H, Irvine AD, Macewen CJ, Weed KH, Porter L, Corden LD et al. Development of allele-specific therapeutic siRNA in Meesmann epithelial corneal dystrophy. PLoS One 2011; 6(12): e28582.

17 Wang LJ, Tian X, Zhang QS, Liu L. [Analysis of mutation in KRT12 gene in a Chinese family with Meesmann's corneal dystrophy]. Zhonghua Yan Ke Za Zhi 2007; 43(10): 885-889.

18 Hatzfeld M, Weber $\mathrm{K}$. The coiled coil of in vitro assembled keratin filaments is a heterodimer of type I and II keratins: use of site-specific mutagenesis and recombinant protein expression. J Cell Biol 1990; 110(4): 1199-1210.

19 Liu CY, Zhu G, Westerhausen-Larson A, Converse R, Kao $\mathrm{CW}$, Sun TT et al. Cornea-specific expression of K12 keratin during mouse development. Curr Eye Res 1993; 12(11): 963-974.

$20 \mathrm{Lu} \mathrm{X}$, Lane EB. Retrovirus-mediated transgenic keratin expression in cultured fibroblasts: specific domain functions in keratin stabilization and filament formation. Cell 1990; 62(4): 681-696

21 Moll R, Franke WW, Schiller DL, Geiger B, Krepler R. The catalog of human cytokeratins: patterns of expression in normal epithelia, tumors and cultured cells. Cell 1982; 31(1): $11-24$

22 Corden LD, McLean WH. Human keratin diseases: hereditary fragility of specific epithelial tissues. Exp Dermatol 1996; 5(6): 297-307.

23 Lane EB. Keratin diseases. Curr Opin Genet Dev 1994; 4(3): 412-418.

24 Ishida-Yamamoto A, McGrath JA, Chapman SJ, Leigh IM, Lane EB, Eady RA. Epidermolysis bullosa simplex (Dowling-Meara type) is a genetic disease characterized by an abnormal keratin-filament network involving keratins K5 and K14. I Invest Dermatol 1991; 97(6): 959-968.

25 Coulombe PA, Hutton ME, Letai A, Hebert A, Paller AS, Fuchs E. Point mutations in human keratin 14 genes of epidermolysis bullosa simplex patients: genetic and functional analyses. Cell 1991; 66(6): 1301-1311.

26 Chaloin-Dufau C, Sun TT, Dhouailly D. Appearance of the keratin pair K3/K12 during embryonic and adult corneal epithelial differentiation in the chick and in the rabbit. Cell Differ Dev 1990; 32(2): 97-108.

27 Nishida K, Honma Y, Dota A, Kawasaki S, Adachi W, Nakamura Tet al. Isolation and chromosomal localization of a cornea-specific human keratin 12 gene and detection of four mutations in Meesmann corneal epithelial dystrophy. Am J Hum Genet 1997; 61(6): 1268-1275.

28 Corden LD, Swensson O, Swensson B, Smith FJ, Rochels R, Uitto J et al. Molecular genetics of Meesmann's corneal dystrophy: ancestral and novel mutations in keratin 12 (K12) and complete sequence of the human KRT12 gene. Exp Eye Res 2000; 70(1): 41-49.

29 Irvine AD, Coleman CM, Moore JE, Swensson O, Morgan $\mathrm{SJ}, \mathrm{McC}$ arthy JH et al. A novel mutation in KRT12 associated with Meesmann's epithelial corneal dystrophy. $\mathrm{Br} J$ Ophthalmol 2002; 86(7): 729-732. 